\begin{tabular}{|l|c|c|}
\hline $\begin{array}{l}\text { Word and Text } \\
\text { A Journal of Literary Studies and Linguistics }\end{array}$ & Vol. XI & $147-158$ \\
\hline
\end{tabular}

\title{
Writing Animality in Yoko Tawada's Memoirs of a Polar Bear
}

\author{
Jamie Johnson
}

Nova Southeastern University

E-mail: jjohnson1@nova.edu

\begin{abstract}
Yoko Tawada, an author writing in both Japanese and German, is what critics call an exophonic writer, that is, a writer who uses a language other than one's mother tongue for creative purposes. Writing from a foreign point of view is part of Tawada's interest in acquiring perceptions of otherness both linguistically and culturally. We might apply Tawada's exophonic writing when entering animal worlds by creating what Frederike Middelhoff terms 'literary auto-zoographies'. Tawada's novel Memoirs of a Polar Bear contains three generations of polar bear narratives: two circus performers and one zoo inhabitant. The text takes a postmodern metafictional approach to problems that arise in speaking for the animal other, a subject under much discussion in Animal Studies scholarship today. My article examines each of the three characters and their corresponding narrative modes. First, the grandmother polar bear writes a first-person autobiography of her life as a performer; in doing so, Tawada combines fiction and nonfiction to deconstruct the bear character's identity thus resulting in what might be called a more authentic animal autobiography. Second, the article focuses on Tawada's fascination with translation through the human-animal shared spaces between Tosca (the daughter of the unnamed grandmother polar bear character) and her human trainer. Lastly, the article examines the grandson, Knut, as an example of the current humanimal subject of ecopoetics with an emphasis on Knut as an environmental figure.
\end{abstract}

Keywords: anthropomorphism, metafiction, ecopoetics, nonhuman, animal, narrative, Franz Kafka, animal studies, postmodernism, posthumanism, autobiography, hybridity, Yoko Tawada

The nature of animal narratives has evolved significantly in the twentieth and twentyfirst century. Historically, their pre-modern function in folklore and animal tales remained rooted in allegory, often with didactic purposes relaying anthropomorphic interpretations. However, the modern literary animal brings experimental subjective accounts of animal being, providing authors a way to create and subsequently explore an alternate nonhuman world of perception and experience. Perhaps the most exemplary accounts of such literature includes Kafka's famous animal narratives ${ }^{1}$ Kafka's animals

\footnotetext{
${ }^{1}$ Kafka's popular animal narratives include 'The Metamorphosis', 'A Report to an Academy', and 'A Hunger Artist'; whereas, a few of the less anthologized stories are 'The Burrow', 'Josephine the Singer, or Mouse Folk', and 'Investigations of a Dog'. While many past writings do not address Kafka's wide variety of animal beings, a more recent collection of essays attempts to tackle the diverse range of animals in Kafka from symbolic to existential. (March Lucht and Donna Yarri (eds.), Kafka's Creatures: Animals, Hybrids, and Other Fantastic Beings (Plymouth: Lexington Books, 2010)).
} 
push the boundaries of human perception by placing value in animal agency in its own right; that is, his texts show a movement from a primarily anthropocentric aim to valuing an animal other's perception of being-in-the-world in-itself. ${ }^{2}$ Jacob von Uexküll, a biological theorist writing around the same time as Kafka at the turn of the century, also addresses animal being-in-the-world, imagining the world of nonhuman animals through a scientific approach. In fact, Uexküll's ideas influence Heidegger, hence the concept of 'being-in-the-world'. Uexküll's theories and Kafka's animal fiction apply to Tawada in that they build on animal conceptions of identity and environment building. Uexküll is known for his theory of Umwelt, 'an animal's perceptual life-world'. ${ }^{3}$ Uexküll believed that each species experiences space, time and communication differently, depending on the individual species' goal and desires, or in phenomenological terms, intentionality. These nonhuman animal worlds, as Uexküll points out, are unknown to humans, and sometimes even invisible. He provides dozens of accounts of animal Umwelt, but one that seems particularly striking is that of the tick. He explains,

The eyeless creature finds the way to its lookout with the help of a general sensitivity to light in the skin. The blind and deaf bandit becomes aware of the approach of his prey through the sense of smell. The odor of butyric acid, which is given off by the skin glands of all mammals, gives the tick the signal to leave its watch post and leap off. ${ }^{4}$

Thus, this tiny being has its own specialized Umwelt, of which humans must use a combination of scientific knowledge and imagination to understand. The lifeworld of each being includes the feel, sensory experience, and aims for continued existence. We see Kafka's contemporary, Virginia Woolf, write on the moth world in 'The Death of the Moth'. Similarly, Kafka imagined the Umwelt of an insect in The Metamorphosis when Gregory Samsa begins as a human character while the reader watches him transform into a foreign insect being. ${ }^{5}$ The reverse transformation occurs when Red Peter moves from animal (ape) to human being. Kafka's nonhuman animal depictions are notably examined by Deleuze and Guattari as 'becoming animal'. ${ }^{6}$ Much of the critical animal studies scholarship continues to identify the trouble with speaking for the other. Today, animal narratives that provide an account of 'what it is like to be' an animal often use recurring features and functions. ${ }^{7}$ One such commonly used narrative device in creating an animal world involves a function of defamiliarizing a reader with his/her conventional perception and simultaneously empathizing with the animal voice at hand. Bernaerts et al. call this tactic a 'double-dialectic' in which one's perspective

\footnotetext{
2 Jacques Derrida, The Animal That Therefore I Am, ed. Marie-Louise Mallet, trans. David Wills (New York: Fordham University Press, 2008). Derrida refers to the Heideggerian term 'being-in-the-world' (11, $79,152,153)$ when discussing how animals are not merely symbols in literature, but live, intending beings.

3 Jakob von Uexküll, A Foray into the Worlds of Animals and Humans, trans. Joseph D. O'Neil (Minneapolis: University of Minnesota Press, 1934), 3.

${ }^{4}$ Uexküll, 44-45.

5 Franz Kafka, The Metamorphosis and Other Stories, trans. Joyce Crick, Intro and Notes Ritchie Robertson (Oxford and New York: Oxford University Press, 2009).

${ }^{6}$ Gilles Deleuze and Félix Guattari, A Thousand Plateaus: Capitalism and Schizophrenia, trans. and Foreword Brian Massumi (London: Continuum, 2004).

${ }^{7}$ Thomas Nagel, 'What Is It Like to Be a Bat?', The Philosophical Review 83.4 (October1974): 435-50.
} 
shifts from a normalized, human-centered view through a kind of becoming animal. ${ }^{8}$ The opening lines of Tawada's novel serve as an example of such a tactic as Memoirs of a Polar Bear immediately throws the reader into a polar bear's world:

\begin{abstract}
I was so small, so lacking in knowledge, so newly in the world. Without my fluffy pelt, I'd have been scarcely more than an embryo. I couldn't walk very well yet, though my pawhands had already developed the strength to grasp and hold [...] Fog shrouded my field of vision, and my ears were echo chambers. Everything I saw and heard lacked contours. My life force resided, for the most part, in my claw-fingers and tongue. ${ }^{9}$
\end{abstract}

Written in first-person point of view, the young, vulnerable polar bear describes her bodily experiences using sensory language. While the phenomenological experience is relatively foreign, we might note the human-animal term, 'paw-hands,' an unexpected hyphenated combination of words which relate to both humans and polar bears. Entering the internal life of the bear through the process of the 'double-dialectic' often aims at destabilizing a reader's anthropomorphic inclinations, including conventional ideas of reality, knowledge and identity. The following essay will focus on Tawada's selected narrative modes for each of the three sections of the novel. We will see that Tawada's fiction recognizes animal tales and critical studies of the past, attempting to carve her own path in the world of animal narratives.

\title{
The Unnamed Grandmother: Animal Autobiography
}

The concept of animal autobiography as a narrative mode challenges the categorical understanding of animals, both for the writer and the reader. Recent animal research may prove that animals communicate through sound and gesture, but an animal, of course, cannot write his/her own autobiography. Creating such a text, then, demands much imagination from the writer and reader. Of course, human autobiographies are, by definition, nonfiction texts; they depict one's life story accurately and realistically from a first-person point of view. While the reader of animal autobiographies knows that animals cannot relate their life stories, one might argue that an animal autobiography engages in both fiction and nonfiction, creating a hybridity between the two genres. With the intention no longer allegorical in aim, writers like Tawada use specific, scientifically driven information on the narrating animal in developing a cognitive illusion. Thus, Tawada combines both the actual world of animals and also creatively 'plays' with alternate world building that do not parallel reality.

Species-specific bear desires pervade Memoirs of a Polar Bear; for example, we see constant references to temperature with the bear's home of Berlin described as pervasively hot. The grandmother bear often fantasizes of living in a colder climate:

I dreamed of a frozen city in which the walls of all the buildings were made of transparent ice. Instead of cars, salmon swam through the streets [. . . Some nights, the heat held me in its grip and wouldn't let me fall into sleep. Although it was February, the temperature rose to above freezing. I made up my mind once and for all to emigrate to Canada. $(M P B, 45)$

\footnotetext{
${ }^{8}$ Lars Mernaerts, Marco Caracciolo, Luc Herman and Bart Vervaeck. 'The Storied Lives of Non-Human Narrators', Narrative 22.1 (January 2014), 69.

${ }^{9}$ Yoko Tawada, Memoirs of a Polar Bear, trans. Susan Bernofsky (New York: New Directions, 2014$), 3$. Hereafter $M P B$, with page numbers in the text.
} 
This attention to environment not only realistically signals an arctic bear's actual inclinations, the temperature also points to the contemporary reader's everyday reality: global warming and extinction of the particular species. Of course, when reading the bear opinions, on another level, the reader is aware that polar bears do not speak English nor do they articulate their expressions through writing. With that said, another example of biological bear-ness appearing throughout the text is in regard to smell. All three bear characters speak of smell regularly; the sense is interspersed within their narrative, making it a fundamental part of their world. For instance, when recalling early memories as a cub, the grandmother bear explicitly notes the intensity of her sense of smell:

\begin{abstract}
My sense of smell was the most reliable of all my five senses and has remained so to this day. When I hear a voice, this doesn't always mean the bearer of the voice is present. A gramophone or a radio can produce a voice as well. My eyesight can't be trusted. A stuffed gull or a human being dressed in a bearskin are nothing more than facades designed for deception. But with smells, I'm not so easily fooled. I can smell whether a person smokes, likes to eat onions, has on new leather shoes, or is menstruating. The scent of perfume cannot cover up a sweaty armpit or the smell of garlic. To the contrary: It underscores these other smells, apparently unbeknownst to human beings. $(M P B, 29)$
\end{abstract}

The human world is not as conscious of smell as a bear, rather, the human sensory experience relies heavily upon the visual, a sense the bear finds unreliable. Thus, the text imagines a foreign sensory aspect of being-in-the-world. However, the way in which the bear expresses her story in the first-person, recalling childhood memories, is much like the human experience and traditional autobiography form. These unfamiliar notions of smell and environment combined with the familiar human writing style return us to Middelhoff's concept of the 'double-dialectic' in which the text provides familiarity and empathy simultaneously. The effect is a shift in perception which blurs epistemological boundaries by placing limitations on language. In the novel, animals can communicate effectively across nonhuman animal species; yet, they cannot always effectively engage via language with humans (an inability never clearly explained in the text), thus they often use alternate modes of being, including sensory and otherworldly forms of communication such as dreams. In fact, bears do not share the same rights as humans in the novel; they are what we might term a minority population, fighting for their rights actively through labor unions, etc.

As the grandmother bear writes the autobiography, she contemplates the act of writing itself. Thus, as Tawada writes the story for the bear, the animal contemplates writing her own story. She even reads Kafka's famous nonhuman animal narrative 'A Report to an Academy' thus Tawada deliberately raises the awareness of the trouble with writing for the animal other. Tawada's choice in layering narratives calls upon another contemporary writer, J.M. Coetzee, who similarly grapples with notions of speaking for the animal other. In his text, The Lives of Animals, a character named Elizabeth Costello delivers a lecture on Kafka's 'A Report to an Academy'. ${ }^{10}$ To clarify, in real life, Coetzee delivered the tale at a Tanner lecture at Princeton University in 1997-1998. Thus, Coetzee, (the author in present day) delivers a live reading of an

\footnotetext{
${ }^{10}$ Franz Kafka, Selected Stories, ed and trans. Stanley Corngold (New York: Norton, 2007).
} 
account of a fictional woman (Elizabeth Costello) delivering a lecture on the fictional ape character, who in the story delivers his lecture to the academy on what it is like to become human. Thus, we have a clever multi-layered metafiction at play. While Tawada's chosen narrative method refers to Coetzee, it differs from his text in that she has a bear contemplating the becoming-human process of the ape.

\begin{abstract}
It struck me as the pinnacle of apishness to not only want to become human but to tell the story of one's own transformation. I imagined an ape aping a human being, and my back immediately started to itch unbearably, as though lice and fleas were dancing the twist in my fur. The ape narrator apparently believed he had written a success story. But if you asked me, I'd lose no time telling you I don't consider it progress to walk on two legs. I felt sick to my stomach remembering how, as a child, I'd learned to walk on two legs. $(M P B, 51)$
\end{abstract}

In Kafka's ape autobiography, he imitated human speech and mimicked human civility in his eloquence. The ape-turned-human described his capture from the wild with utmost rational language and articulation. He shows intelligence that matches that of the human mind in order to assimilate into a human world, resulting in power and independence. In Tawada's fictional world, animals do not need to make this transformation, in fact, the polar bear's purpose in writing the autobiography remains directed toward reconstructing her bear identity. When she articulates the writing process, she relates it to bear-ness: 'Writing isn't particularly different from hibernation. Perhaps I made a drowsy impression, but in the bear's den of my brain, I was giving birth to my own childhood and secretly attending to its upbringing.' (MPB, 15) Furthermore, the bear's agent, Sea Lion, makes her writing mission clear: 'What your readers want to know is how you mastered the high art of stagecraft without losing your wildness, and what that felt like.' $(M P B, 31)$ What appealed to Red Peter's audience was how he transformed himself from wild to human. The polar bear's autobiography seeks ways to retrieve her wildness. The re-construction of her identity calls for a return to nature and her arctic environment, a necessary aspect of her bear-hood.

\begin{abstract}
As a child I was constantly under pressure and always had to go to bed early so I could get up again at the crack of dawn to start my training. There had been a phase before my childhood began, one in which no clock ever ticked. I gazed at the moon, felt the sun's rays on my fur, and observed the gradual alternation of bright and dark, a series of tiny shifts. Falling asleep and getting up were not my own private concerns, they were the work of Nature. When my childhood began, Nature came to an end. Now I want to find out what happened to me before childhood. (MPB, 25-26)
\end{abstract}

Taken from the North Pole as a cub, the matriarch spent her life performing in the Berlin circus. Middelhoff says of Tawada's three bear generations: Although the bears are institutionalized and trained, taken from their wild homes, they retain a 'material, corporeal presence as bears'. ${ }^{11}$ Therefore, while Tawada's novel obviously tackles serious topics such as identity structures and global warming, there is also a keen level of irony and playfulness in the narrative that should be acknowledged. We do not see such tone in a writer such as Coetzee, for example. Tawada's texts move into an area of

\footnotetext{
${ }^{11}$ Frederike Middelhoff, '(Not) Speaking for Animals and the Environment: Zoopoetics and Ecopoetics in Yoko Tawada's Memoirs of a Polar Bear', in Texts, Animals, Environments: Zoopoetics and Ecopoetics, ed. Frederike Middelhoff et al. (Freiburg: Rombach Verlag, 2019), 347.
} 
magical realism and fantasy, as seen in the coming analyses. In this way, her texts require attention to narrative mode.

\section{Tosca: Translation and Human-Animal Intersections}

Very few writers produce literature outside of their original language. ${ }^{12}$ Tawada grew up in Japan, speaking only Japanese. As an adult, she moved to Germany, at which time, she began writing in both Japanese and German. John Pizer calls Tawada 'a true authorial polyglot' because she writes as much in her mother tongue as she does in her non-native host language. ${ }^{13}$ According to Pizer, 'Tawada's stories and poetry are hyperconscious of the avenues through which transnational cultural exchange is mediated in and through language, [she] evokes a planetary hybridity rooted in a practice of border-crossing relationality.' ${ }^{14}$ While Tawada's writing shows a consciousness of language, as demonstrated by Pizer, in crossing these linguistic borders, her purpose is not to categorically define the avenues separately, as one might be inclined; instead, she uses the movement between linguistic worlds to further her artistic craft. During an interview with Bettina Brandt, Tawada explains her interest in translation by referring to the German word for 'to translate [übersetzen]' which can also mean 'to steer a boat from one shore to the other'. ${ }^{15}$ In Japanese, 'to translate' means 'to turn over' or 'to flip over'. Taking these translations into account, Tawada claims that she 'likes to visualize the act of translation' as an act that 'makes it possible to show the flipside of something in an unexpected way'. ${ }^{16}$ In another interview on translation with Monika Totten, Tawada extends the discussion of translation when speaking of the necessary loss of power as a writer in a foreign language. ${ }^{17}$ For her, this loss is an experimental advantage to be embraced rather than feared: 'It's exciting too, to lose yourself [. . . T This is a condition similar to mediation or the trance of the shaman in that you empty yourself in order to be receptive, to accept foreign voices which, in fact, are not foreign but very familiar.' ${ }^{18}$ Translation, then, with its ability to 'flip' or 'turn' a perspective is much like the narrative task of writing the nonhuman animal world. As such, the trouble with 'los[ing] yourself' or becoming 'empty' to accomplish the translation also applies to moving into an imagined animal world. The following section will show Tawada's inclusion of language translation in creating what we might call a shared 'humanimal' space.

The second section of Memoirs of a Polar Bear moves from the grandmother bear's autobiography to the story of her daughter, Tosca. Like her mother before she retired, Tosca is a performer in the circus. The section begins in the first-person

\footnotetext{
${ }^{12}$ John D. Pizer, 'Planetary Poetics: World Literature, Goethe, Novalis, and Yoko Tawada's Translational Writing', in The Planetary Turn: Relationality and Geoaesthetics in the Twenty-First Century, ed. Amy J. Elias and Christian Moraru (Evanston, IL: Northwestern University Press, 2015), 17.

${ }^{13}$ Pizer, 17.

14 Pizer, 5.

${ }^{15}$ Bettina Brandt, 'Scattered Leaves: Artist Books and Migration, A Conversation with Yoko Tawada', Comparative Literature Studies 45.1 (2008): 21.

${ }^{16}$ Brandt, 21.

${ }^{17}$ Monika Totten and Yoko Tawada, 'Writing in Two Languages: A Conversation with Yoko Tawada', Harvard Review 17 (Fall 1999): 93-100.

${ }^{18}$ Totten and Tawada, 95.
} 
human narrative voice of Barbara, Tosca's trainer. A kind woman, Barbara wishes to understand Tosca's perception, yet the text informs us that the human and animal characters 'lack a common language'. Because Tosca requires human help to write, Barbara decides to compose Tosca's biography. Thus, similar to the grandmother bear's section, we return to the thematic issue of narrative authority and the theoretical trouble with telling an animal's story. Tawada's characters resolve linguistic limitations by entering a shared world, one that in literary terms would most likely fall under the category of magical realism. The fantastical shared space is highly hybridized and relational, weaving in and out of the human (Barbara's) and animal (Tosca's) worlds, full of fragmented memories and ontological experiences. However, during the act of writing Tosca's biography, Barbara's own self-identity resists entering Tosca's world due to Barbara's childhood memories and personalized identity overwhelming her consciousness.

One day Barbara announces to the bear: "I've started writing your biography," [she] said to Tosca, who sneezed in surprise.' (MPB, 123-4) She explains:

\footnotetext{
'I promised to write down your life story. But so far I've only been talking about my own. I'm terribly sorry.'

'That's all right. First you should translate your own story into written characters. Then your soul will be tidy enough to make room for a bear.'

'Are you planning to come inside me?'

'Yes.'

'I'm scared.'

We laughed with one voice. $(M P B, 138)$
}

Tawada shows Barbara's writing as a slow process of losing herself. As she writes, Barbara's own human memories, fears, and desires fill the text. Although Barbara's goal is to write Tosca's biography, she finds herself inadvertently writing her own story. During the writing process, Barbara's dreams allow her to enter a space in which she can converse with Tosca.

I saw the black flame in Tosca's pupils flicker. Everything around me was filled with light, so bright it blinded me and made the line dividing the wall from the ceiling disappear. I still felt no fear of Tosca, but there was something frightening in the atmosphere surrounding her. I'd entered a realm where it was forbidden to set foot. And there, in darkness, the grammars of many languages lost their color, they melted and combined, then froze solid again, they drifted in the ocean and joined the drifting floes of ice. I sat on the same iceberg as Tosca and understood every word she said to me. Beside us floated a second iceberg with an Inuk and a snow hare sitting on it, immersed in conversation. $(M P B, 98)$

Notably, the new realm involves a surreal change not only in environment, but in the foundation of language. The nature of language appears to structurally breakdown, only to then reassemble from fluid substance to solid water, thus the ice itself on which the characters sit creates a place of conversing between human and animal. And it is not just Tosca and Barbara in the realm; other species cross linguistic borders to converse on passing floats of ice as well. This shared space does not resemble Barbara's Umwelt, instead, Barbara is displaced into what is arguably a polar bear's arctic world. Moreover, Barbara acquires bear-like capabilities we saw in the grandmother bear, such as a loss of vision and increase in smell. Tosca and Barbara meet in this space regularly, conversing about each other's childhood experiences, developing a bond 
between the two based on shared childhood memories. In fact, the two identities become indiscernible as the chapter moves on. Near the end of the section, a bold, black pawprint mark on the page solidifies the end of Barbara's point of view. After the pawprint mark, the text changes tone and suddenly, in the first person, Tosca says: 'Barbara and I decided on a certain finale for our act without informing Pankov and Markus. We rehearsed in our shared dream.' Just as Tawada describes translation as a 'flip' or 'turn over' from one side of the shore to the other, perception flips from Barbara to Tosca. And, in the closing paragraphs to the section, once again, Tawada returns to language when Tosca describes her perception of what it was like to enter a human world.

I saw her soul flickering in the depths of her dark throat [. . .] her human soul had passed bit by bit into my bear body. A human soul turned out to be less romantic than I'd imagined. It was made up primarily of languages - not just ordinary, comprehensible languages, but also many broken shards of language, the shadows of languages, and images that couldn't turn into words'. $(M P B, 163)$

Tawada describes the human soul in terms of language, but one that is indiscernible, thus language cannot explain one's internal life, instead, the language had to be altered as seen in the previous shared space between Barbara and Tosca. Importantly, Tawada does not portray language as a format that must be eliminated in order to lay the groundwork for a different, new state of nonlinguistic being; instead, language changes, becomes 'broken' into 'shards' and 'shadows' as is the case in movement from one language to another during translation. One might discern that the limits of language call for use of more primal images of lightness and darkness, as Tawada seems to turn to imagery and the body; in both instances of movement into the shared space, Tawada describes a 'flicker' occurring in the body. In the end of the section, Barbara dies leaving Tosca contemplating writing Barbara's biography. As if rhetorically convincing herself to write the biography, Tosca says, 'What bear in the past had ever before succeeded in writing down the life of a human friend?' Therefore, the section that began with a human writing the story of an animal ends with the reverse: a bear writing the story of a human.

\section{Knut: Zoo Life and Ecopoetics}

The third and final section of the novel focuses on what we might call ecopoetics. In the context of the polar bear, ecopoetics involve the contemporary issue of animal extinction and global warming. Tawada's decision in telling the story of three polar bears, with the original bear taken from the wild and bred in captivity, points toward the ethical element of animal lives in the current Anthropocene. Middelhoff calls the Knut section of the novel an 'auto-zoopoetics of negativity' through which the depiction of Knut in literature leads the reader outside of the fictional world and into the ethical world to which the text refers. ${ }^{19}$ Thus, the reader becomes aware that polar bears in the real world are in danger of extinction from loss of habitat. In terms of the dangers of life in captivity, polar bears such as Knut are prone to depression and heat stroke. A handful of contemporary authors today also engage in such narrative theory that incorporates

\footnotetext{
${ }^{19}$ Middelhoff, 348.
} 
ecocriticism. For instance, Chen Yingsong's novel, The Last Dance of a Leopard, contains an entire nonhuman animal narrative from the perspective of a dead animal, a leopard, who was cruelly hunted and killed by humans.

To summarize Tawada's novel by movement in narrative by section, in the first section, Tawada's metafiction appears through narrative authority in references to Kafka and the act of writing. Section two problematizes point of view through the 'humanimal' hybrid shared space and its relationship to language. Continuing in her interplay of fiction and nonfiction as it relates to the narrative form of biography, Knut (the grandson of the grandmother bear from section one and the son of Tosca from section two) is based on an actual bear who lived at the Berlin Zoo in 2009. Abandoned by his mother, he was raised from a fragile age by a zookeeper. His entire life from cub to adulthood was seen in the public sphere; the bear cub became a famous international celebrity, drawing crowds at the zoo daily with thousands of followers and fans. Then, one day in his enclosure, at the young age of four, Knut suddenly collapsed and died in front of zoo spectators. Scientists later claim his death was caused by a disease, antiNMDA receptor encephalitis involving autoimmune inflammation of the brain, an illness never before found in nonhuman animals. While Tawada's depiction of Knut's story does not end with his death, the novel's basic story of his life matches that of reality quite closely, even down to the description of Knut's stone enclosure.

Although Knut's fictional life includes details from reality, consistent with the rest of the novel, Tawada presents the reader with Knut's uniquely bear-like subjective perspective of the world. Knut's bear perspective differs from that of the other two bears in that the reader watches Knut's consciousness evolve from bear infancy. The other two bear characters are adults when presented to the reader, having already undergone training through the human lifeworld. Thus, the context of the grandmother and mother bear's childhood is purely understood through retrospective memory or through the shared space seen in section two. In watching Knut's mind evolve, the reader, at one point, sees the young Knut experience an epiphany. The moment occurs while Knut goes for walks in the zoo, a special allowance made for Knut, requested by his human 'mother,' the scientist named Matthais.

\footnotetext{
Knut suddenly saw the familiar stone slab before him. 'That's the enclosure where you always play.' Marveling, Knut stared at this familiar place that he was seeing from a new angle. The cheers of the visitors were activated in his memory. So this was the other side, the reverse of the stage. But what did that mean, the reverse? Knut felt his brain cells begin to twitch. The gray matter revolved slowly around its axis and something from the middle flew out. What was that just now? Knut gazed up at the sky, something was different from before. If he could just view everything from above, he would never again be startled by a change in perspective. $(M P B, 204)$
}

In this passage, Tawada shows the imagined neuroscience of Knut's brain activity. The bear's stream of consciousness is mapped in its most minute details. The reader watches, as if in slow motion, as the bear's perspective changes from 'being viewed' to 'becoming the viewer'. Later, another important development occurs in Knut's consciousness that alters the narrative entirely. The narrative voice in the Knut section begins in what appears to be third-person. It is only when Knut speaks with a fellow zoo animal in captivity when he, along with the reader, realizes that Knut has been naively referring to himself in the third-person for the first half of the section. As soon as Knut becomes conscious of this linguistic error on his behalf, he begins speaking in the first- 
person, a narrative tone which carries through to the end of the novel. These shifts in Knut's perspective return to the topic of zoo life, in particular Knut's epiphany. Like his family members before him, Knut is essentially a performer. Although not a circus performer, Knut is the object of human spectatorship. The shift in his perspectival thought shows his ability to see himself from the human point of view, a selfconsciousness also reflected in his identity building in the linguistic first-person recognition of 'I'.

Similar to section one with the unnamed grandmother and section two with Tosca, Knut becomes interested in his personal identity. In line with all three generations of bears, the bears do not look to their lives in domestic captivity in search of their origins, rather, they all look to the arctic wilderness. In the case of the grandmother, she was taken as a cub form the wild, yet the two other bears were born in captivity; thus, the images in their minds are not memory-based, yet Tawada describes the arctic places are clearly the same. That is, all three bears seem to return to a shared arctic image or place in their minds. For the grandmother (when performing in the circus), her consciousness returns to her experience in the world of ice.

\begin{abstract}
My round, soft upper body is encased in sumptuous white fur. When I press my raised right arm and rib cage slightly forward, hypnotically shimmering particles of light are released into the air. Yes, I was at the center of everything, while the tables, walls and the people in the audience gradually faded and withdrew into the background. My fur's gleaming white hue is unlike any ordinary white. It's translucent, permitting the sunlight to reach my skin through the fur, and the light is carefully stored beneath my skin. This is the color my ancestors acquired, allowing them to survive in the Arctic Circle. $(M P B, 5)$
\end{abstract}

The world in which Barbara and Tosca share in Barbara's dreams is the same world seen in the grandmother's consciousness, the place of their ancestors. In section three, Knut sees this place in his dreams as well. He converses with what is described as a 'gigantic Snow Queen' who is 'ancient - so old that her age transcended years'. She stands in a space of 'endless snowfields' donning a 'snowy coat'. (MPB, 194) When Knut asks her if she is his grandmother, she replies that she is 'the superimposition of numerous ancestors' $(M P B, 213)$. In terms of animal history, humans do not normally speak of nonhuman animals as having ancestors, particularly spiritual advisors. This is a human concept that Tawada applies to animals. Animal ancestry might cause one to turn to Darwinian evolutionary theory, in which instinct and primal drives lay at the root of the animal consciousness. In her highly experimental novel, Virginia Woolf tried her hand in writing a nonhuman animal narrative through a cocker spaniel in Flush: A Biography. ${ }^{20}$ The narrative, much like that of Kafka and Tawada, attempts to relay the world according to a dog. However, Woolf begins the dog's story with a focus on canine ancestry, specifically Cocker Spaniel ancestry. Demonstrating extensive research on the subject, Woolf traces Flush's origins by way of the Spaniel 'family'. The novel's opening lines express Flush's heritage: 'It is universally admitted that the family from which the subject of this memoir claims descent is one of the greatest antiquity. ${ }^{21}$ Similarly, Tawada shows a concern for a singular animal's history with particular attention to identity building. Acknowledging an animal's history perhaps refers us back

\footnotetext{
${ }^{20}$ Virginia Woolf, Flush: A Biography, ed. Trekkie Ritchie (New York: Harcourt, 1983 [1933]).

${ }^{21}$ Woolf, 3.
} 
to Derrida's claim that one cannot refer to animals as categorically grouped together under the linguistic terminology of 'animals' as such language limits animal subjectivity as individual beings. If a subject is to have an identity or a story, one must recognize the subject's family ancestry, along with all of their collective memories, experiences, fears, emotions, etc. Humans are accustomed to viewing the lives of animals scientifically according to organized classification. One might argue that in building an identity through three generations of polar bears, Tawada places human conceptions of identity onto animal lives. Tawada's narrative shows a consciousness of her position as a human author expressing the life and identity of the animal other; at the same time, the polar bear voices in her novel make every attempt to self-consciously address those problems of representation.

\section{Bibliography}

1. Brandt, Bettina. 'Scattered Leaves: Artist Books and Migration, A Conversation with Yoko Tawada'. Comparative Literature Studies 45.1 (2008): 12-22.

2. Deleuze, Gilles, and Félix Guattari. A Thousand Plateaus: Capitalism and Schizophrenia. Translation and Foreword by Brian Massumi. London: Continuum, 2004.

3. Derrida, Jacques. The Animal That Therefore I Am. Edited by Marie-Louise Mallet. Translated by David Wills. New York: Fordham University Press, 2008.

4. Kafka, Franz. The Metamorphosis and Other Stories. Translated by Joyce Crick. Introduction and Notes by Ritchie Robertson. Oxford and New York: Oxford University Press, 2009.

5. Kafka, Franz. Selected Stories. Edited and Translated by Stanley Corngold. New York: Norton, 2007.

6. Lucht, March, and Donna Yarri (Editors). Kafka's Creatures: Animals, Hybrids, and Other Fantastic Beings. Plymouth: Lexington Books, 2010.

7. Middelhoff, Frederike. '(Not) Speaking for Animals and the Environment: Zoopoetics and Ecopoetics in Yoko Tawada's Memoirs of a Polar Bear'. In Texts, Animals, Environments: Zoopoetics and Ecopoetics. Edited by Frederike Middelhoff et al. Freiburg: Rombach Verlag, 2019. 339-54.

8. Mernaerts, Lars, Marco Caracciolo, Luc Herman and Bart Vervaeck. 'The Storied Lives of Non-Human Narrators'. Narrative 22.1 (January 2014): 68-93.

9. Nagel, Thomas. 'What Is It Like to Be a Bat?' The Philosophical Review 83.4 (October 1974): 435-50.

10.Pizer, John D. 'Planetary Poetics: World Literature, Goethe, Novalis, and Yoko Tawada's Translational Writing'. In The Planetary Turn: Relationality and Geoaesthetics in the Twenty-First Century. Edited by Amy J. Elias and Christian Moraru. Evanston, IL: Northwestern University Press, 2015. 3-24.

11. Tawada, Yoko. Memoirs of a Polar Bear. Translated by Susan Bernofsky. New York: New Directions, 2014.

12.Totten, Monika, and Yoko Tawada. 'Writing in Two Languages: A Conversation with Yoko Tawada'. Harvard Review 17 (Fall 1999): 93-100.

13.Uexküll, Jakob von. A Foray into the Worlds of Animals and Humans. Translated by Joseph D. O’Neil. Minneapolis: University of Minnesota Press, 2010.

14.Woolf, Virginia. Flush: A Biography. Edited by Trekkie Ritchie. New York: Harcourt, 1983 [1933]. 


\section{Scriind animalitatea în romanul lui Yoko Tawada Memoriile unui urs polar}

\section{Rezumat}

Critica literară îl asimilează pe Yoko Tawada, care scrie în limba japoneză și în limba germană, unui scriitor exofonic, adică unui scriitor care folosește în scop creator literară o limbă diferită față de cea maternă. Scriind din perspectiva străinului este de altfel o parte integrantă a preocupării lui Tawada de a înregistra percepțiile unei alterități lingvistice și culturale. Am putea să folosim scriitura exofonică a lui Tawada atunci când intrăm în lumea animalelor, creând ceea ce Frederike Middelhoff numește „autozoografii literare”. Romanul lui, Memoriile unui urs polar, conține trei generații de narațiuni ale urșilor polari: doi dintre ei performează la circ și unul este închis într-o grădină zoologică. Textul abordează ca metaficțiune postmodernă probleme ce sunt ridicate de modalitatea de a comunica cu animalul, o problematică ce este în dezbatere în studiile actuale despre animale. Articolul meu examinează fiecare dintre aceste trei personaje și narațiunile lor. În primul rând, bunica urs polar scrie o autobiografie la persoana întâi despre viața ei ca artistă la circ; astfel, Tawada combină ficțiunea cu nonficțiunea pentru a deconstrui identitatea personajului urs, astfel rezultând ceea ce am putea numi o autobiografie a animalului care este mai mult decât autentică. În al doilea rând, articolul se concentrează pe fascinația lui Tawada în legătură cu traducerea dintre spațiile uman-animal care apar între Tosca (fiica bunicii urs polar care nu are un nume) și îmblânzitorul ei uman. În ultimul rând, articolul examinează nepotul, Knut, ca exemplu al subiectului umanimal actual, subiect al ecopoeticii, cu o atenție sporită acordată personajului Knut ca figură a mediului. 